\title{
Sustainable development entrepreneurship formation: system-integrated management tools
}

\author{
Svitlana Filyppova ${ }^{1, *}$, Yurii Kovtunenko ${ }^{1}$, Volodymyr Filippov ${ }^{1}$, Lidiia Voloshchuk $^{1}$, and \\ Oleksandr Malin ${ }^{1}$ \\ ${ }^{1}$ Odessa National Polytechnic University, Odessa, 1 Shevchenko prosp., 65044, Ukraine
}

\begin{abstract}
Entrepreneurship ensures the development of both the national economy and the population's, well-being so it embodies a necessary process and factor for ensuring sustainable development. In the long run, sustainability is impossible without development and the entrepreneurship as one of its main stakeholders plays a triple role, acting at the same time as a significant factor, part of the economic component and a mechanism ensuring the sustainable development. The article examines issues of sustainable development entrepreneurship; considered is the substantial characteristics of management tools for system-integrated sustainable development entrepreneurship management, thus offering a system of digital tools services for sustainable development entrepreneurship digital platform and model for sustainable development entrepreneurship. The theoretical and methodological approaches to business development management proposed are designated to provide management focusing on sustainable development, system-integrated nature, anticipatory influence, use of rapidly growing digital capabilities, therefore forming an innovative basis for management and its object development. Its components are: a system of digital tools, a model of socially responsible business ideas and business projects selection; business models for sustainable development entrepreneurship. The study results are of essential practical importance for the process of one's own business conducting with the use the rapidly growing opportunities opening.
\end{abstract}

\section{Introduction}

The socio-economic environment of economic management in Ukraine remain quite difficult, so the Ukrainian sustainable development model is formed in the conditions of a prolonged economic crisis and unbalanced, to say depressive in certain periods development of entrepreneurship. However, global trends in sustainable development and innovative information economy generation create new opportunities to develop the entrepreneurship and to promote its collaboration. Its development, regardless of the scale, is increasingly taking place due to the combination of innovative, information and communication components. Therefore opening are the new opportunities for entrepreneurship management that require entrepreneurs new competencies and changes in

\footnotetext{
${ }^{*}$ Corresponding author: y.v.kovtunenko@opu.ua
} 
the theoretical and methodological basis of entrepreneurship management as well as its models.

The entrepreneurship and sustainable development problems were studied both separately and in certain combinations, in particular, such authors as: B. Burkinsky [1], M. Voynarenko [2], K. Kovtunenko [3], O. Kuzmin [4], N. Shlafman, [1], S. Muhr [5], S. Goyal [6], are analyzing business functions and business environment, its main organizational forms, goals, problems of financing, pricing, information; and the authors: L. Nekrasova [7], V. Stadnyk [8], L. Frolova [9], J. Pollack [10], M. Zarefard [11] are considering the entrepreneurs' links with the government and society, programs aimed to adjust the business and government structures' main line, competition development, business strategies and tactics.

At the same time, the existing global trends in innovative information economies formation and the sustainable development of countries created new challenges to entrepreneurship varied from new opportunities opening to the obstacles for its development. This requires a new approach to the entrepreneurship development management, namely, a system-integrated management technique.

\section{Methods}

This research theoretical and methodological basis refers to the innovations and systems theories' provisions, modern economic concepts of informatization, business management and sustainable development. The research used a systematic approach to the socioeconomic phenomena study, in particular, based on the fundamental provisions of economic theory, economic analysis and decision-making methodology. Apart that a comprehensive approach uniting the general scientific and special methods is used: empirical research and content analysis methodology to substantiate the information and innovation sustainable development entrepreneurship platform; and classification and logical-substantive modeling methods were applied to develop a system-integrated approach to the entrepreneurship development managing in compliance to sustainable development imperatives, its conceptual business model, information and analytical tools.

\section{Results and discussion}

The Sustainable Development Entrepreneurship is understood as the entrepreneurship aimed at achieving the sustainable development goals at the respective tasks level in the process of one's own business activities implementing. This is a new type of entrepreneurship, when the sustainable development goals are turning into natural ones, basically crucial for that entrepreneurship existence. Here the entrepreneurial ideas, expectations, entrepreneurial behavior, and entrepreneurial activities differ from traditional industrial and post-industrial entrepreneurship.

The system-integrated management of sustainable development entrepreneurship formation refers to managing a new historical phenomenon as a new object, to say, a new socio-economic phenomenon that is currently being born.

This object management shall be carried out using the new management tools, which development involves the following stepwise stages:

- management tools content characteristics;

- development of an entrepreneurship collaboration model for sustainable development using the resources of information and innovation digital platform for sustainable development entrepreneurship;

- elaborating a model for infrastructure entrepreneurship development. 
The content characteristics of system-integrated management tools for sustainable development entrepreneurship development management consist in description of its composition and purpose, functionality, profile format and competence base.

A. Composition and purpose. The management tools are represented by three groups: 1) macro level (national), 2) meso level (regional, industry) and 3) micro level (level of a management subject, that are an entrepreneurial structure, a state institution, a charitable or public organization, an association of enterprises, etc.).

As to the macro level: it should be noted that the management tools of the first two levels do immediately depend on the economic management model and the model of its transition to sustainable development, and the micro level group tools are sequentially dependent on the same. At that, the state regulation of entrepreneurship development should be transformed according to the sustainable development imperatives.

The system of digital tools is visualized by the services available at the digital entrepreneurship management platform for sustainable development, every one being directed to achieve its own goals system (Fig. 1) [12, 13].

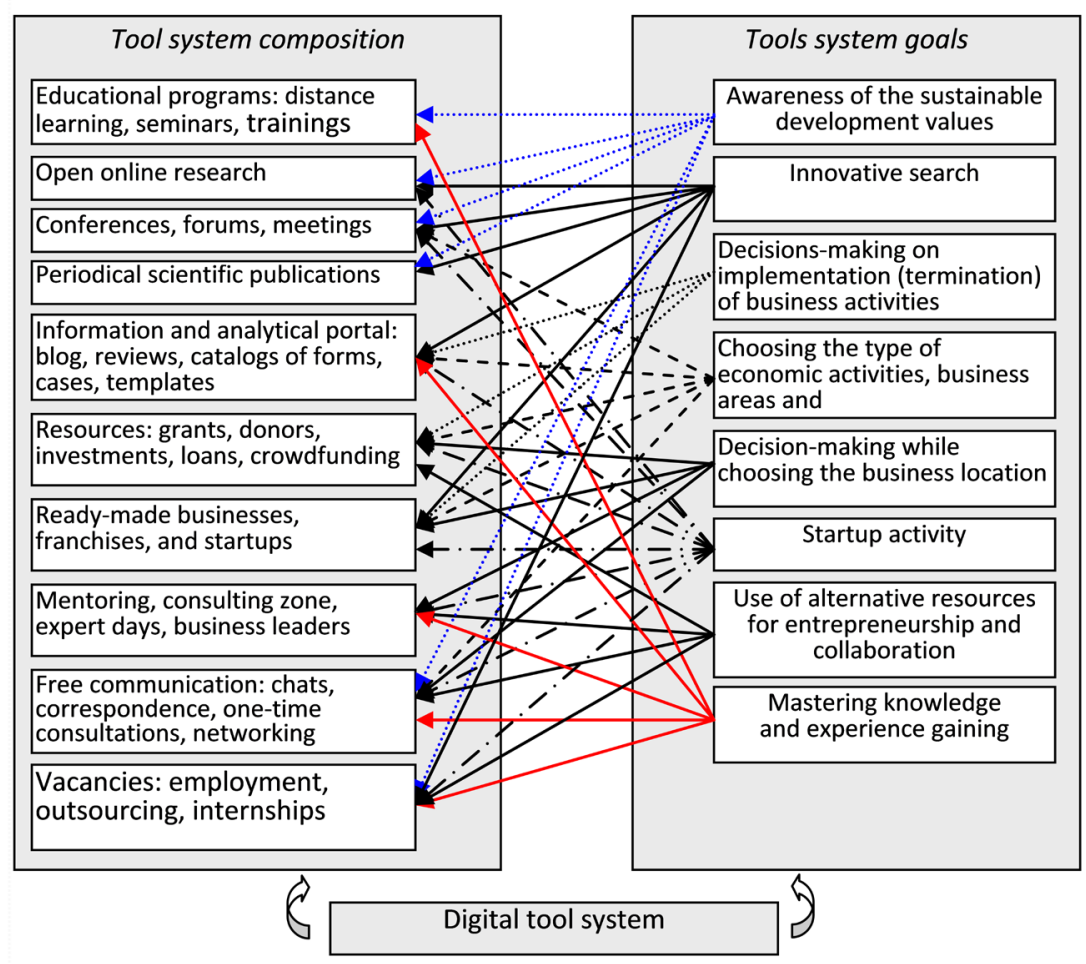

Fig. 1. Goals and composition of the digital tools system as services available at the digital enterprise management platform for sustainable development.

In particular, the following management tools for sustainable development entrepreneurship system-integrated management at the micro level make part to the tools inventory:

- system of digital tools represented by the sustainable development entrepreneurship management digital platform services;

- model of socially responsible selection of entrepreneurial ideas and entrepreneurial projects; 
- business models for sustainable development entrepreneurship, its rapid assessment directions and tools.

A. 1 The digital tools system covers the services available at the digital platform for managing sustainable development entrepreneurship, and selected based on the results of content analysis as to their content and general impact on the entrepreneurship formation as well as the feasibility of using to enable the sustainable development entrepreneurship formation.

Accordingly, to achieve each of the above listed entrepreneurship goals used shall be several digital tools-services of the digital platform for managing sustainable development entrepreneurship, which can be supplemented with offline activities. Of course, this way is more beneficial for small and microenterprises, self-employed businessmen.

A. 2 Business models for sustainable development entrepreneurship, directions and tools for its rapid assessment depend on several factors that reflect the sustainable development values:

- initial state and potential of nine units of entrepreneurship:

1) customers, - their willingness to use new services and products, the presence of an already formed market segment;

2) the product value revealing as its raw material composition environmental friendliness, wastes produced while operation and packaging, and its disposal complexity;

3) channels of interaction (trading, sales, etc.) in terms of their ability to ensure the purity of interaction, impact on the environment, resource consumption;

4) customer relations - joint solution of problems as to the waste temporary storage and disposal, disposal of goods sold (manufactured products);

5) sources of income (income flows): their list expansion and introduction of sustainable development entrepreneurship (business sector expansion, increased prices for organic products, compensation of expenses by state programs, etc.);

6) key resources: their environmental friendliness, limitations, and availability;

7) key processes (types of activities) - their resource saving characteristics, environmental impact and impact on the sustainable development entrepreneurship development, collaboration availability and potential in new areas of sustainable development entrepreneurship;

8) key partners, their weight, compliance with the sustainable development values (1-9 units of entrepreneurship array),

9) costs structure: availability, share, and dynamics of changes in environmental protection costs, acquisition of resource-saving technologies, and innovative search.

- entrepreneur's goals as his vision of the own business goals, its role in sustainable development ensuring according to the mentioned entrepreneurship array units, his plans for the future, etc.

Accordingly, the business model for Sustainable Development Entrepreneurship should take into account both groups of factors, so it changes, acquiring the form as below (Fig. 2) $[12,13]$.

As evident from Fig. 2, the entrepreneur's social responsibility areas are expanded to cover all nine units of entrepreneurship array and form its growth points (PZ1-PZ8). These points represent the use of corresponding units' potential. Growth points do not form those units' parts that are marked 1.2, 8.2, because these are consumers/customers segments (1.2) and segments of partners (8.2) who do not yet care about sustainable development never perceiving its values at the stage of starting a certain entrepreneur's business activity. It is advisable to single them out immediately as a segment impractical for primary collaboration and relationships starting. However, the management macro level task for them remains unchanged: acknowledgment with sustainable development principles and knowledge getting in that field. 


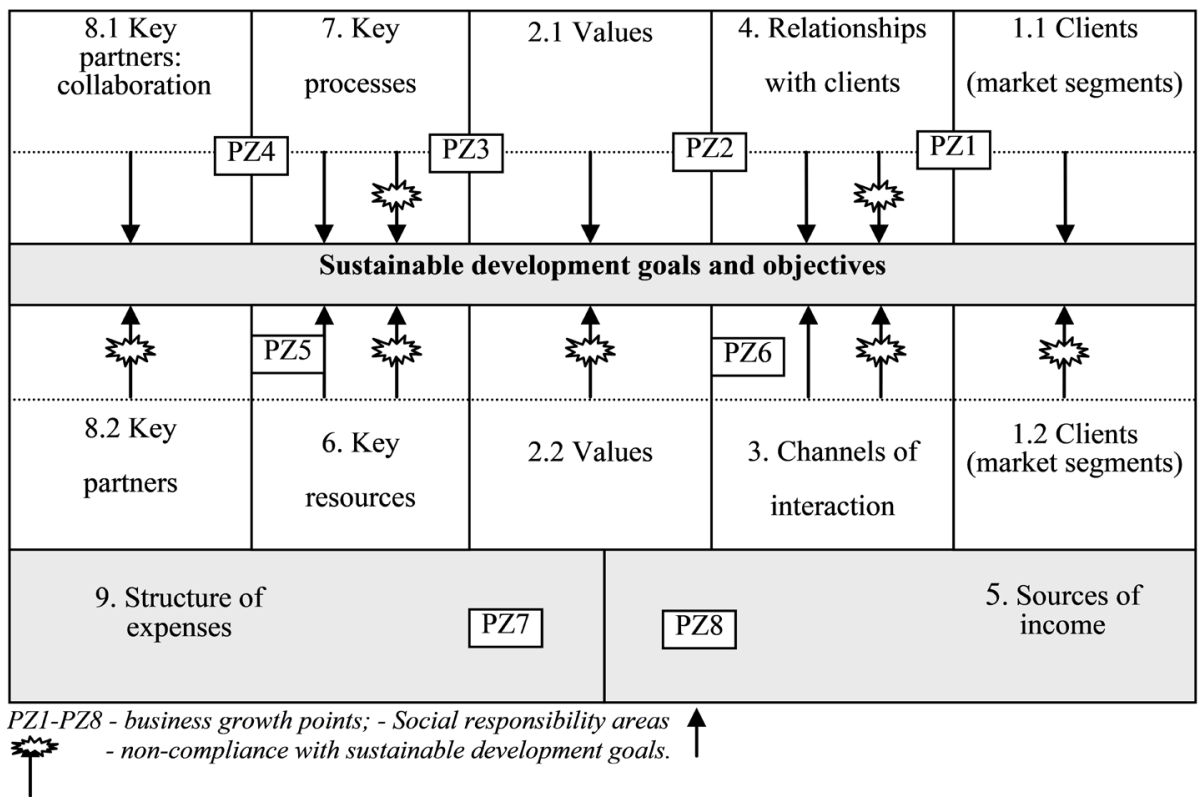

Fig. 2. Business model for sustainable development entrepreneurship: growth points, areas of social responsibility.

Apart those, there are and may further exist the interaction channels (3), customer relationships (4), key resources (6) and key processes (7) that partially do not meet the sustainable development goals and are not aimed at achieving its goals and its tasks solving. It is advisable to revise such ones by reengineering or evolutionary improvement, depending on the available resources. You can't get rid of these units, because business activity will stop without them. In particular if we are talking about certain chemical raw materials or low-quality land resources when no alternative exists.

The business model shown in Fig. 2, is just the one advisably recommended to:

- contractors under grants: advised to include the self-employment, microenterprise, small businesses incubation and acceleration programs in training classes on entrepreneurship bases. This will allow evidencing a clear link between the sustainable development and a specific business;

- entrepreneurs: advised for using to develop a structured and logical, understandable business scheme clearly characterised by the sustainable development entrepreneurship indices.

A. 3 The model of entrepreneurial ideas and entrepreneurial projects socially responsible selection represents a tool for competitive selection of entrepreneurial ideas and projects, proposed in order to support just those aimed at sustainable development and solving its specific tasks

Entrepreneurial ideas and projects are divided into two groups based on ideas and projects beneficiaries' typology:

a) innovative ideas and projects for grants. This array of ideas is intended for subjects carrying out the sustainable development entrepreneurship management at the macro-and micro-levels as grantees, which can be listed as: charitable foundations, public organizations, public associations, scientific, educational and scientific institutions, and separate individuals-innovators in accordance with the specific grants awarding conditions;

B) business ideas and projects for independent implementation (collaboration). This array of ideas is intended for self-employed individuals and business entities in the micro, small and medium-sized business sectors. 
The directions and tools of its rapid assessment are presented in (Table 1), from which it can be generalized that impractical shall be using the complex assessment methods at the business starting stage, since that can scare off the potential entrepreneurs. It is appropriate to focus on content analysis, a mini-max approach, and use the clear tools, all that contributing to a better understanding of the future of some given business. In further development and business reorganization, it is possible to use more complex algorithms, still these essentially simpler than the algorithms for evaluating large companies [13-15].

Table 1. Directions and tools for rapid assessment of the business model for sustainable development entrepreneurship.

\begin{tabular}{|l|l|}
\hline \multicolumn{1}{|c|}{ Evaluation direction } & \multicolumn{1}{c|}{ Evaluation tools } \\
\hline 1. Business model complexity & $\begin{array}{l}\text { content analysis, matrix of strategic alternatives, } \\
\text { Ishikawa Kaoru diagram, logical and content } \\
\text { modeling (goal tree); }\end{array}$ \\
\hline 2. business model effectiveness & $\begin{array}{l}\text { calculation of the economic effect, break-even } \\
\text { point, profitability of activity; }\end{array}$ \\
\hline 3. business model cost and expenses & $\begin{array}{l}\text { development of estimates for the operating cycle, } \\
\text { calendar period (month, year); }\end{array}$ \\
\hline 4. business model components layout & $\begin{array}{l}\text { scenario analysis, logical and content modeling } \\
\text { (decision tree); }\end{array}$ \\
\hline 5. advantages and disadvantages of model & SWOT analysis, ranking; \\
\hline $\begin{array}{l}\text { 6. business model's ability to meet the } \\
\text { sustainable development challenges }\end{array}$ & content analysis, point method, strategic mapping. \\
\hline
\end{tabular}

The business model effectiveness is also considered from two angles: economic growth and sustainable development (Table 2).

Table 2. Evaluating the business model effectiveness in terms of sustainable development entrepreneurship.

\begin{tabular}{|c|c|c|c|}
\hline \multirow{2}{*}{$\begin{array}{l}\text { Angle of } \\
\text { evaluation }\end{array}$} & \multicolumn{3}{|c|}{ Evaluation characteristics } \\
\hline & character & evaluation purpose & evaluation object \\
\hline \multirow{5}{*}{$\begin{array}{l}\text { 1. Economic } \\
\text { growth }\end{array}$} & - internal & $\begin{array}{l}\text { - maximization of profit } \\
\text { (income); }\end{array}$ & - use of potential; \\
\hline & - external & - collaboration effectiveness; & - using external opportunities; \\
\hline & - general & - business value growth; & - business value; \\
\hline & - expenses-based & - expenses feasibility; & - business expenses; \\
\hline & - target value & - achieving business goals; & - target performance; \\
\hline \multirow{3}{*}{$\begin{array}{l}\text { 2. Sustainable } \\
\text { development }\end{array}$} & - target value & $\begin{array}{l}\text { - solving certain sustainable } \\
\text { development goals; }\end{array}$ & - target performance; \\
\hline & - resource -based & - resource constancy; & $\begin{array}{l}\text { - resource saving; } \\
\text { - resource structure; }\end{array}$ \\
\hline & - result-based & $\begin{array}{l}\text { - socio-ecological and } \\
\text { economic results and } \\
\text { consequences; }\end{array}$ & $\begin{array}{l}\text { - number of jobs created; } \\
\text { - environmental impact, } \\
\text { business environmental } \\
\text { footprint. }\end{array}$ \\
\hline
\end{tabular}

It is also suggested that at the stage of starting a business, entrepreneurs should never be overloaded with a large amount of calculations, so proposed are simple approaches easy to visualize and understand. In particular, the methodology for ecological footprint calculating as a measure of human needs and impact in the planet's ecosystem, presented on websites such as "Education for Sustainable Development in Action" [16], can be easily adapted to the self- employed as well as quickly adapted for micro and small businesses. The results of testing to assess the most economical option of existence do reflect significant structural changes in human needs and features of its existence currently. 


\section{Conclusions}

The development of entrepreneurship as a process involves consequences manifested at different levels (mega, macro, meso, micro) and in various spheres (innovation, social, economic, technological, scientific, environmental), enabling changes in the world, national, industry and regional scale, while changing entrepreneurs and relevant enterprises. It can be noted that:

- the system-integrated management of the sustainable development entrepreneurship development, in other words of a new object, - the Sustainable Development Entrepreneurship, which is now being born, should apply fundamentally different tools at all (macro-, meso - and micro-) management levels;

- such management tools inventory composition in the information and innovation economy shall provide those tools systemically integrated character, focusing on sustainable development goals, proactive impact, use of rapidly growing opportunities for informatization and digital aspect, forming an innovative basis for the management and development of those tools application object;

- the tools inventory composition at the micro level is formed by: a) the system of applied digital tools which are services provided by the digital platform for managing sustainable development entrepreneurship; b) a set of methodological tools and approaches, in particular: 1) entrepreneurial ideas and entrepreneurial projects socially responsible selection model; 2) business models for sustainable development entrepreneurship, directions and tools for its rapid assessment.

\section{References}

1. Burkynskyi, B., Laiko, O. \& Shlafman N. (2020). Strategic directions for increasing the productivity of entrepreneurial activity in Ukraine. Economic Innovations, 22(4(77)), 7 18. https://doi.org/10.31520/ei.2020.22.4(77).7-18

2. Voinarenko, M. \& Kostyuk, O. (2013). Sutnist ta principi biznes-administruvannya na pidpriyemstvah za umov minlivogo konkurentnogo seredovisha. Ekonomika: realiyi chasu, 4 (9), 49-51. https://economics.opu.ua/files/archive/2013/No4/49-51.pdf

3. Kovtunenko, K. (2013) The laws and the main dominants of machine-building enterprises development in conditions of strategic changes. Economic Annals-XXI, 56(1), 75-78.

4. Kuzmin, O., Bublyk, M., Shakhno, A., Korolenko, O. \& Lashkun, H. (2020). Innovative development of human capital in the conditions of globalization. E3S Web of Conferences, 166, 13011. https://doi.org/10.1051/e3sconf/202016613011

5. Muhr, S., Cock, C., Twardowska, M. \& Volkmann C. (2019) Constructing an entrepreneurial life: liminality and emotional reflexivity in identity work. $\begin{array}{llll}\text { Entrepreneurship \& } \quad \& \quad \text { Regional } & \text { Development. } & \text { 31:7-8, }\end{array}$ https://doi.org/10.1080/08985626.2019.1596348

6. Goyal, S., Sergi, B.S., \& Esposito M. (2018) Business development services for micro, small and medium enterprises - literature review of past trends and future directions. World Review of Entrepreneurship, Management and Sustainable Development (WREMSD). 14(3), 312-332. Chukurna, O., Niekrasova, L., Dobrianska, N., Izmaylov, Ya., Shkrabak, I. \& Ingram K. (2020) Formation of methodical foundations for assessing the innovative development potential of an industrial enterprise. Naukovyi Visnyk Natsionalnoho Hirnychoho Universytetu 4, 146-151. https://doi.org/10.33271/nvngu/2020-4/146 
7. Stadnyk, V., Izhevskiy, P., Zamazii, O., Goncharuk, A. Melnichuk, O. (2018). Factors of enterprises' strategic selection of participation forms in integration formations. Problems and Perspectives in Management. 16. 90-101. http://dx.doi.org/10.21511/ppm.16(2).2018.09

8. Frolova, L., Ivanchuk, K., Nosova, T., Horodetska, T. \& Zaychenko, K. (2019). Evaluation of informational provision quality of food industry enterprises flexibility management. Journal of Hygienic Engineering and Design. 28, 66-72.

9. Pollack, J., Maula, M., Allison, T., Renko, M. \& Günther, C. (2019). Making a contribution to entrepreneurship research by studying crowd-funded entrepreneurial opportunities. Entrepreneurship Theory and Practice, 45, 104225871988864. http://dx.doi.org/10.1177/1042258719888640

10. Zarefard, M. \& Cho, S.E. (2018) Entrepreneuršr managerial competencies and innovative start-up intentions in university students: focus on mediating factors. International Journal of Entrepreneurship. 22(2). 1-22.

11. Kovtunenko, K., Filippova, S., Poberezhets, O., Kovtunenko, Y. \& Stepanchenko. A. (2019). Adaptation of the logistics system of food industry enterprises in conditions diversification of activities. Journal of Hygienic Engineering and Design. 27, 108-113.

12. Filippov, V. (2020). Management tools of system-integrated enterprise development management. Economic journal Odessa polytechnic university. 1. 64-76. http://dx.doi.org/10.15276/EJ.01.2020.8

13. Prokopenko, O. \& Omelyanenko, V. (2018). Marketing aspect of the innovation communications development. Innovative Marketing. 14(2), 41-49. http://dx.doi.org/10.21511/im.14(2).2018.05.

14. Bashynska, I.O. (2016) Using SMM by industrial enterprises. Actual Problems of Economics. 12 (186), 360-369.

15. Education for Sustainable Development in Action (2021). http://esd.org.ua/En 